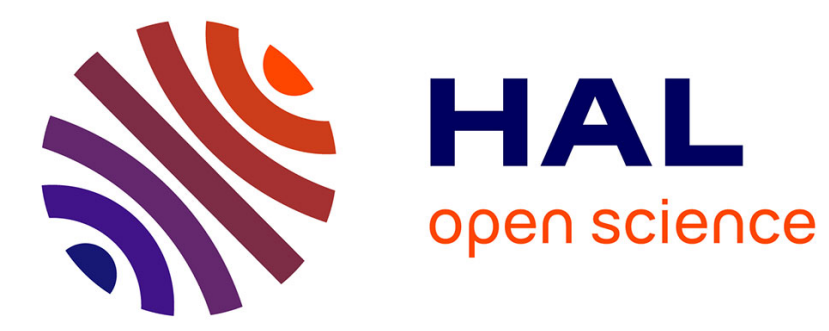

\title{
Preparation of $\beta$-SiC Coatings Using 1,2-Dimethyldisilane as Precursor
}

Xing Tang, R. Haubner, B. Lux, A. Zechmann, E. Hengge

\section{To cite this version:}

Xing Tang, R. Haubner, B. Lux, A. Zechmann, E. Hengge. Preparation of $\beta$-SiC Coatings Using 1,2Dimethyldisilane as Precursor. Journal de Physique IV Proceedings, 1995, 05 (C5), pp.C5-777-C5-784. 10.1051/jphyscol:1995592 . jpa-00253954

\section{HAL Id: jpa-00253954 https://hal.science/jpa-00253954}

Submitted on 1 Jan 1995

HAL is a multi-disciplinary open access archive for the deposit and dissemination of scientific research documents, whether they are published or not. The documents may come from teaching and research institutions in France or abroad, or from public or private research centers.
L'archive ouverte pluridisciplinaire HAL, est destinée au dépôt et à la diffusion de documents scientifiques de niveau recherche, publiés ou non, émanant des établissements d'enseignement et de recherche français ou étrangers, des laboratoires publics ou privés. 


\title{
Preparation of $\beta$-SiC Coatings Using 1,2-Dimethyldisilane as Precursor
}

\author{
X. Tang, R. Haubner, B. Lux, A. Zechmann* and E. Hengge* \\ Institute for Chemical Technology of Inorganic Materials, Technical University of Vienna, Getreidemarkt \\ 9/161, 1060 Vienna, Austria \\ * Institute for Inorganic Chemistry, Technical University of Graz, Stremayrgasse 16, 8010 Graz, Austria
}

\begin{abstract}
A cold-wall upstream reactor was designed to study the deposition of $\beta$-SiC layers on WC-Co hard metal substrates. Experiments demonstrated that $\beta$-SiC coatings can be easily deposited on inductively heated substrates at temperatures between $1000-1400^{\circ} \mathrm{C}$ by thermal decomposition of 1,2-dimethyldisilane under normal pressure conditions. It was shown that this silicon compound is an advanced precursor for the preparation of $\beta$-SiC coatings. The reaction temperature influenced the $\mathrm{SiC}$ growth rate as well as the microstructure of the coating. Different reaction mechanisms occurred at these temperatures. Fine grained cauliflower-like coatings were obtained below $1100^{\circ} \mathrm{C}$ while monolithically crystallised coatings were formed above $1200^{\circ} \mathrm{C}$. These morphological differences are associated with the coating growth rates, which reached a maximum at $1100^{\circ} \mathrm{C}$ and decreased rapidly at higher temperatures. The precursor concentration in the reaction gas had to be kept relatively low in order to obtain homogeneous, crystalline SiC coatings and to prevent "smoking", i.e. nucleation of fine particles in the gas phase.
\end{abstract}

\section{INTRODUCTION}

$\mathrm{SiC}$ exists in many complex crystalline polytypical structures, of which $\beta$-SiC (or $3 \mathrm{C} \mathrm{SiC}$ ) is reported to be the only cubic one. $\alpha-\mathrm{SiC}$ can form hexagonal $(6 \mathrm{H} \mathrm{SiC})$ or rhombohedral crystals [1].

$\mathrm{SiC}$ coatings are widely used scientifically and industrially because of their thermal, mechanical and electronic properties as well as their excellent chemical stability [2,3]. Typical industrial applications are in electronic devices, for protection against chemical corrosion and as hard and wear-resistant materials [4,5]. $\mathrm{SiC}$ could also be used for intermediate layers between the substrates (hard metal or Si-wafer) and CVD diamond coatings. It is already in use as a substrate for such coatings [6].

$\mathrm{SiC}$ coatings are usually prepared by a CVD reaction using silane or its derivatives and a hydrocarbon [7-10]. A major problem with these precursors is the difficulty in obtaining stoichiometric SiC; carbon or silicon excesses or deficiencies are too often found in the final products [11]. Carbon-containing silane derivatives can be excellent precursors for $\mathrm{SiC}$ preparation [12,13]. Among the various possible precursors in systems $\mathrm{Si}-\mathrm{Cl} / \mathrm{Si}-\mathrm{Cl}-\mathrm{H}$, Si-C-H and $\mathrm{Si}-\mathrm{C}-\mathrm{H}-\mathrm{Cl}$, the $\mathrm{CH}_{3} \mathrm{SiCl}_{3}$ (MTS) was very often chosen [14-20]. The studies and processes of SiC films are largely summarized by Schlichting [21] and Besmann [22]. A thermodynamic analysis and kinetic implications of CVD SiC from Si-C-Cl-H systems was described in [23]. A calculation of CVD phase diagrams useful for the preparation of silicon carbide from commonly used precursors was given in [24]. More recently, $\mathrm{SiC}$ polycrystallines were grown by LPCVD using tetramethylsilane (TMS) as precursor [25,26]. One in particular in Si-C-H sysrem, 1,2-dimethyldisilane, has been used in work carried out in a hot-wall reactor. The pyrolytic formation of $\mathrm{SiC}$ showed that both $\mathrm{SiC}$ coatings and powders can be formed simultaneously by thermal decomposition at elevated temperatures. The precursor is easy to handle, is inexpensive and has a carbon-to-silicon ratio corresponding exactly to the stoichiometric ratio of $\mathrm{SiC}$ [27].

For the present work a cold-wall upstream reactor was designed which made $\mathrm{SiC}$ deposition possible without simultaneous powder formation. The WC-Co substrates were inductively heated by a RF source. The pyrolysis of 1,2 -dimethyldisilane was conducted at $700-1400^{\circ} \mathrm{C}$. 


\section{EXPERIMENTAL PROCEDURE}

\subsection{Precursor and substrate}

1,2-dimethyldisilane - a colorless liquid with a boiling point of $48^{\circ} \mathrm{C}$ - has been synthesized at the TUGraz in sufficiently large amounts for CVD reactions, and its preparation method has been presented elsewhere[27]. The compound is volatile and stable for short times in air at room temperature. A determination of the vapor pressure of the compound was done by measuring the equilibrium-boiling temperature under different total pressure of the system and afterwards extrapolating the measured value to low temperature. Figure 1 shows the temperature dependence of its vapor pressure.

WC-6\% Co cemented carbide cutting tools (H21 SNG-432; size: $12.5 \times 12.5 \times 4.5 \mathrm{~mm}^{3}$ ) were used as substrates. Before deposition they were ultrasonically cleaned in methanol solution.

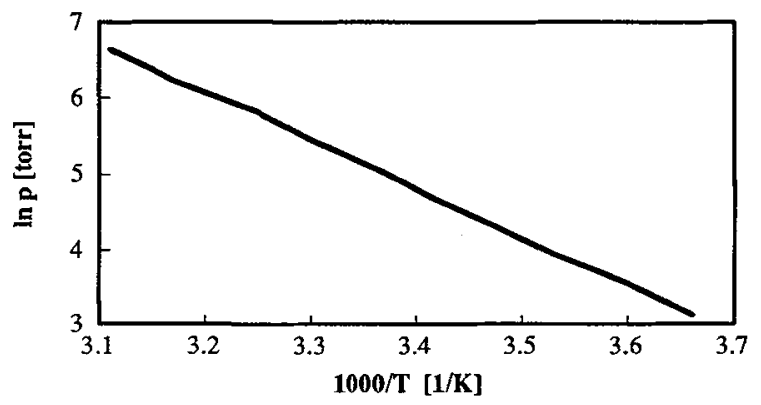

Figure 1: Vapor pressure of 1,2-dimethyldisilane as a function of temperature

\subsection{CVD apparatus and deposition procedure}

The cold-wall CVD apparatus was designed to deposit SiC on WC-Co substrates at different temperatures, precursor concentrations and gas velocities (see Figure 2). With it pyrolytic decompositions under atmospheric pressure or in vacuum can be carried out.

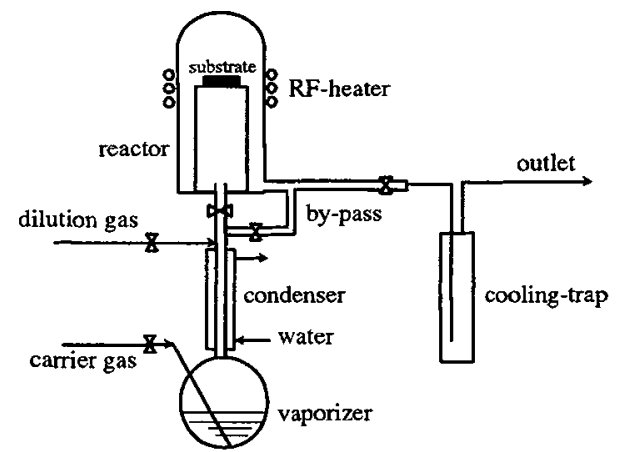

Figure 2: Schematic diagram of the chemical vapor deposition system

The precursor vaporizer with a saturating condenser and the reaction chamber with by-pass and cooling traps were made of Pyrex glass. For the reaction chamber itself a quartz glass tube is needed for depositions above $1600^{\circ} \mathrm{C}$.

Since the presence of oxygen could lead to the formation of silicon oxide the apparatus was flushed with nitrogen for $15 \mathrm{~min}$. prior to each experiment. Hydrogen served as the carrier and dilution gas. The carrier gas passed first through the precursor vaporizer unit held at room temperature $\left(15-20^{\circ} \mathrm{C}\right)$, then 
through the water-cooled condenser, so that it could be saturated by the precursor. The temperature of the condenser was kept at $2^{\circ} \mathrm{C}$ during the entire deposition procedure. At this temperature the vapor pressure of the compound was maintained at 27 torr. After the carrier gas was saturated with the precursor it was diluted by hydrogen to reach the desirable precursor concentration for the deposition process.

A high-frequency induction heating device (type HFS40, frequency $270 \mathrm{KHz}$ ) was used to heat the hard metal. A single WC-Co substrate was placed in the center of the induction coil and heated rapidly (within 30-60 seconds) in a flowing hydrogen atmosphere, whereby the upper temperatures were limited only by the melting point of the cobalt binder phase of the substrate. The precursor/hydrogen mixture flowed upstream through the reaction chamber after the substrate reached the desired constant temperature. The pyrolytic reaction is supposed to take place just on the hot surface of the substrate. After the deposition the substrate was cooled to room temperature under flowing pure hydrogen.

$\mathrm{X}$-ray diffraction was used to determine the composition of the SiC coating and SEM to characterize the morphology. The SiC growth rates were calculated from the weight increases of the substrates.

\section{RESULTS}

Initially a high 1,2-dimethyldisilane concentration of 3.43\% (carrier gas $500 \mathrm{ml} / \mathrm{min}$ and no dilution gas) was used in the gas mixture to produce the SiC coatings. At $700^{\circ} \mathrm{C}$ neither smoking (nucleation in the gas phase) nor coating were observed. Pyrolysis of the precursor obviously occurred at $900^{\circ} \mathrm{C}$, forming both powders in the gas phase and coatings on the substrates surface. The higher the substrate temperature the stronger was the smoking in the gas phase. Based on these results the main deposition parameters were therefore temperatures above $900^{\circ} \mathrm{C}$ and low precursor concentrations in order to produce good coatings without powder formation.

\subsection{The deposition temperature}

Figure 3 shows the growth rates of $\mathrm{SiC}$ coatings at different temperatures.

The experiments were conducted in the range of $900-1400^{\circ} \mathrm{C}$ with a constant precursor concentration $\left(6.28 \times 10^{-2} \% 1,2\right.$-dimethyldisilane in the gas mixture) to prepare coatings without smoke formation. The $\mathrm{SiC}$ growth rate showed a maximum at a substrate temperature of $1100^{\circ} \mathrm{C}$, above which the growth rate decreased rapidly. The deposition temperature of $1100^{\circ} \mathrm{C}$ is also critical for the SiC morphology. At higher temperatures the SiC coatings were crystalline as observed by SEM. At lower temperatures cauliflowerlike coatings were obtained (see Figure 4).

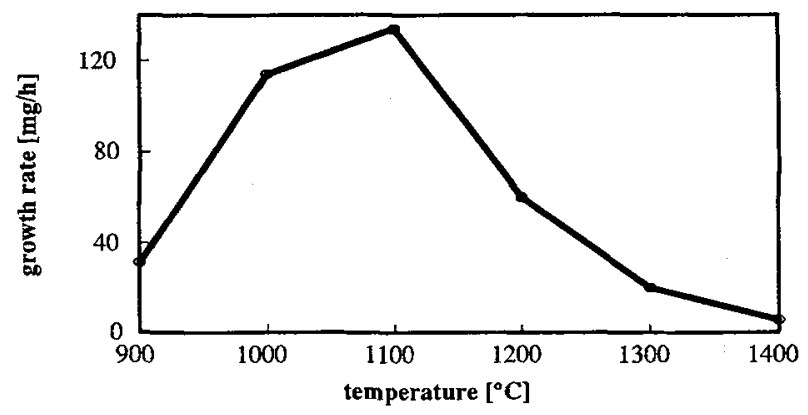

Figure 3: $\mathrm{SiC}$ growth rate at different temperatures $\left(6.28 \times 10^{-2} \%\right.$ precursor, $\mathrm{H}_{2}$ flow $\left.500 \mathrm{ml} / \mathrm{min}\right)$

These changes in crystallinity were also detected by X-ray diffraction. As shown in Figure 5 for lower deposition temperatures $\left(1000^{\circ} \mathrm{C}\right)$ and a high precursor concentration $(3.43 \%)$ the amorphous coatings had formed. However the typical diffraction pattern of $\beta-S i C$ already appeared at the same temperature with a lower precursor concentration $\left(6.28 \times 10^{-2} \%\right)$. At increasing temperatures $\beta$-SiC with good crystallinity was always observed. 
$1000^{\circ} \mathrm{C}$
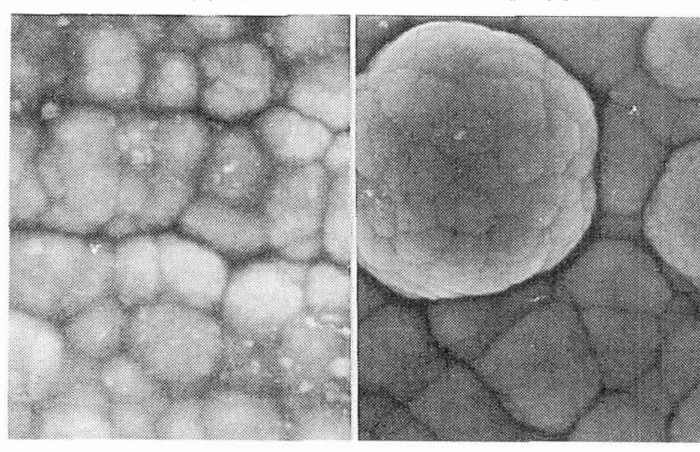

$1200^{\circ} \mathrm{C}$

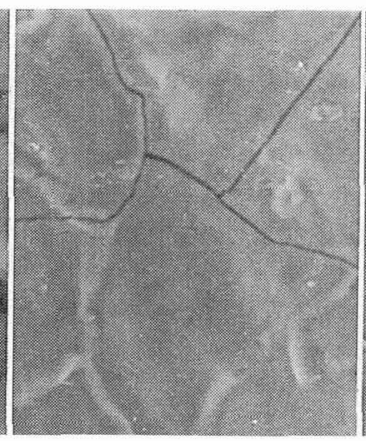

$1300^{\circ} \mathrm{C}$

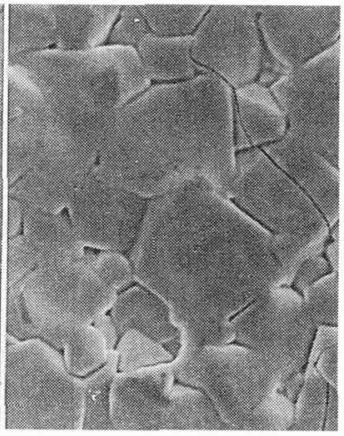

$10 \mu \mathrm{m}$

Figure 4:Morphology changes in $\mathrm{SiC}$ coatings with temperature at a constant precursor concentration $\left(6.28 \times 10^{-2} \%\right.$ 1,2-dimethyldisilane, $\mathrm{H}_{2}$ flow $\left.500 \mathrm{ml} / \mathrm{min}\right)$

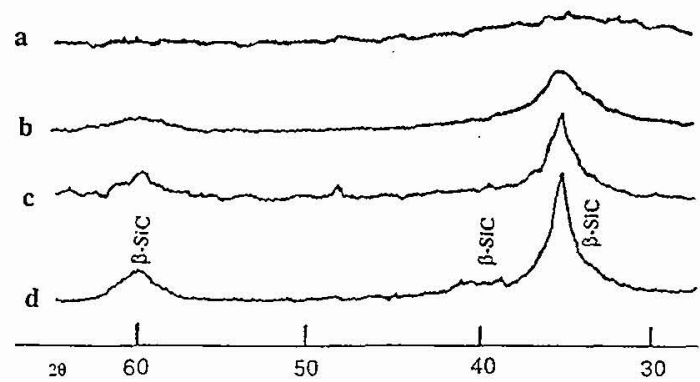

Figure 5: $X$-ray diffraction patterns of coatings deposited at different conditions
a: $1000^{\circ} \mathrm{C}$, precursor $3.43 \%$
b: $1000^{\circ} \mathrm{C}$, precursor $6.28 \times 10^{-2} \%$
c: $1200^{\circ} \mathrm{C}$, precursor $6.28 \times 10^{-2} \%$
d: $1400^{\circ} \mathrm{C}$, precursor $6.28 \times 10^{-2} \%$

\subsection{Deposition with different precursor concentrations}

The influence of the precursor concentration on coating growth rates was studied at the deposition temperature of $1200^{\circ} \mathrm{C}$ (Figure 6). A linear increase of the $\mathrm{SiC}$ growth rate with the precursor concentration was found. The morphologies of the coatings changed with increasing precursor concentration from crystalline to cauliflower-like (Figure 7).

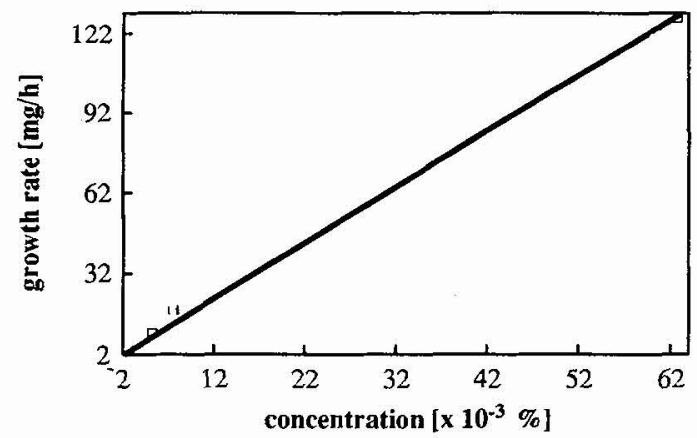

Figure 6: Relationship between coating growth rate and precursor concentration $\left(1200^{\circ} \mathrm{C}, \mathrm{H}_{2}\right.$ flow $\left.500 \mathrm{ml} / \mathrm{min}\right)$ 


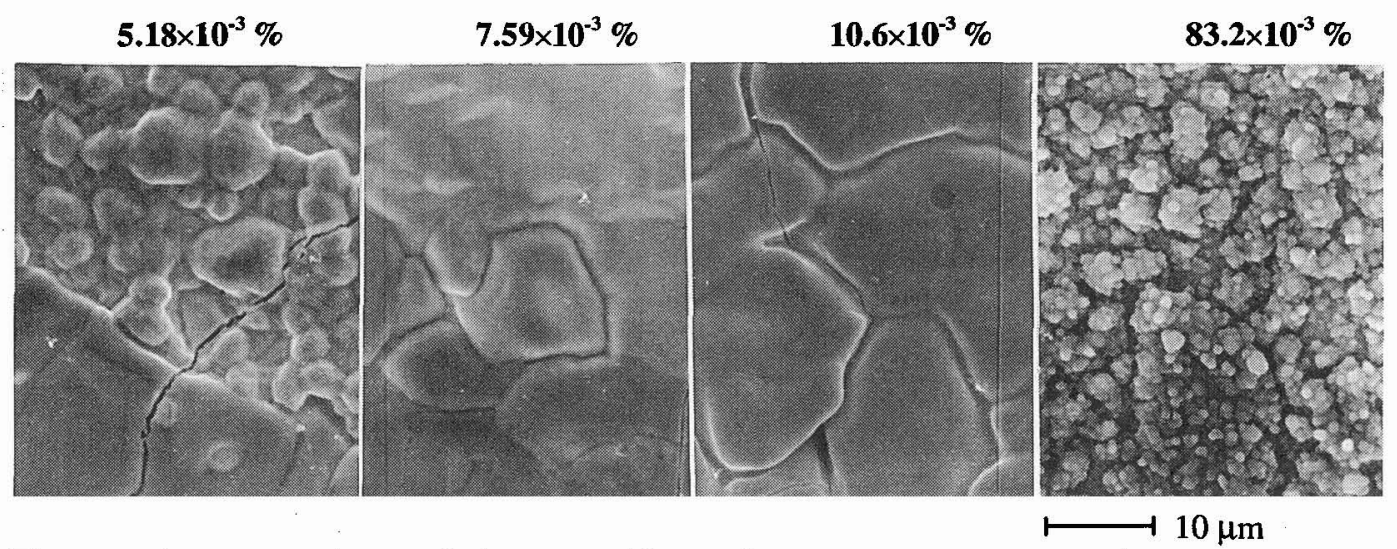

Figure 7: Changes in SiC morphology caused by varying the precursor concentrations (substrate temperature $1200^{\circ} \mathrm{C}, \mathrm{H}_{2}$ flow $500 \mathrm{ml} / \mathrm{min}$ )

\section{DISCUSSION}

With a directly heated substrate and using 1,2-dimethyldisilane as the precursor, the preparation of continuous SiC coatings is quite easy. The deposition temperature and precursor concentration influence the coating growth rate and crystallinity. Films with different morphologies can be produced under different condition. The formation of powders in gas phase can also be avoided by decreasing the precursor concentration.

\subsection{Effects of temperature on the pyrolysis of the precursor}

The thermal decomposition of 1,2-dimethyldisilane can follow different reactions steps :

$$
\begin{aligned}
\mathrm{H}_{2}\left(\mathrm{CH}_{3}\right) \mathrm{Si}-\mathrm{Si}\left(\mathrm{CH}_{3}\right) \mathrm{H}_{2} & \rightarrow \mathrm{SiC}+\mathrm{H}_{2} \\
& \rightarrow \mathrm{SiC}+\mathrm{SiCH}_{\mathrm{n}}+\mathrm{H}_{2} \\
& \rightarrow \mathrm{SiC}+\mathrm{SiCH}_{\mathrm{n}}+\mathrm{CH}_{\mathrm{m}}+\mathrm{H}_{2}
\end{aligned}
$$

The radicals $\mathrm{SiCH}_{\mathrm{n}}$ and $\mathrm{CH}_{\mathrm{m}}$ are formed during the precursor decomposition and can be removed from the apparatus with the flowing hydrogen. It can be further assumed that at the higher temperatures more radicals are formed. However, since these radicals are not decomposed to $\mathrm{SiC}$, a decrease in the $\mathrm{SiC}$ growth rate is observed.

At lower substrate temperatures $\left(900-1100^{\circ} \mathrm{C}\right)$ the precursor species are adsorbed and decomposed on the substrate surface and not in the gas phase. The decomposition temperature influences the diffusion to the substrate and the increase in SiC growth rate can be explained by the higher decomposition rates (higher diffusion to the substrate), while the absence of smoking indicated that no decomposition in the gas phase occurred.

At substrate temperatures above $1100^{\circ} \mathrm{C}$ the precursor decomposes both on the hot surface of the substrate and in the gas phase surrounding it, thus forming not only the SiC coating but also radicals as expressed in reactions (2) or (3). If the radicals cannot reach the substrate surface - where the coating is formed - they are removed by the gas stream.

These effects are important for the crystallinity and morphology of the SiC crystal. The concentration of the precursor species as well as the deposition temperature determine the growth of the coatings. 


\subsection{SiC crystal growth and coating morphology}

\subsubsection{Amorphous $\mathrm{SiC}$}

At $900-1000^{\circ} \mathrm{C}$ the deposited coatings consist mainly of amorphous SiC. At low temperatures the surface mobility is also low and the species arriving from the gas phase cannot readily rearrange. However, by decreasing the precursor concentrations in the gas phase (i.e. reducing the supersaturation at the substrate surface) nucleation of $\beta-\mathrm{SiC}$ became possible even at such low temperatures.

\subsubsection{Monolithic $\beta-S i C$}

At high temperatures and low growth rates, obtained by a low precursor concentration, the formation of a monolithic SiC coating was observed (Figure 8 and 9). Starting from the substrate edges the SiC crystals grow towards the center. This can be explained by the gas flow in the tube type reactor where the gas flow rate is a maximum at the substrate edges. Under these conditions the nucleation rate is very slow and the crystals grow together, forming large homogeneous areas. Very thin coatings were observed. If the SiC coating does not fully cover the substrate, the boundary between the coating and the hard metal surface is linear, looking like crystal facets. Depending on the precursor concentration these "monocrystalline" areas can reach several $\mu \mathrm{m}$ in diameter. Some of these monocrystals at the edge are even as big as 50-80 $\mu \mathrm{m}$.
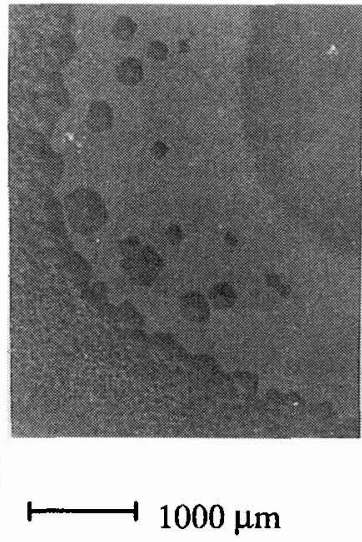

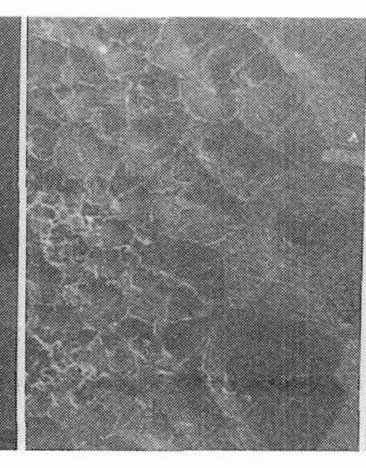

$\longmapsto 100 \mu \mathrm{m}$

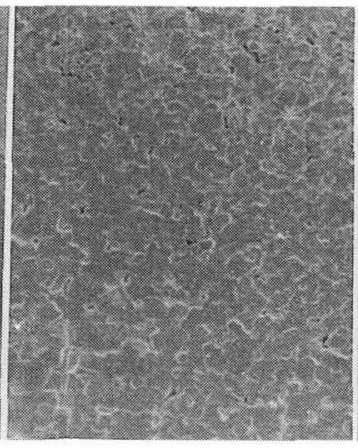

$\longmapsto 100 \mu \mathrm{m}$

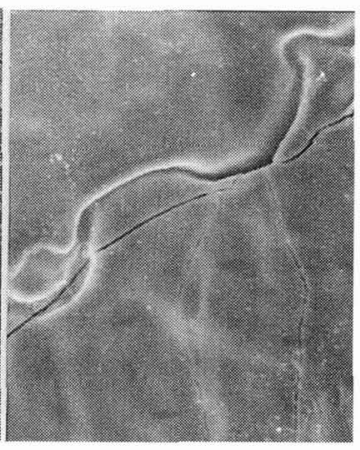

$\longmapsto 10 \mu \mathrm{m}$

Figure 8: Monolithic $\mathrm{SiC}$ layers $\left(1200^{\circ} \mathrm{C}, 7.59 \times 10^{-3} \%\right.$ precursor, $\mathrm{H}_{2}$ flow $\left.500 \mathrm{ml} / \mathrm{min}\right)$

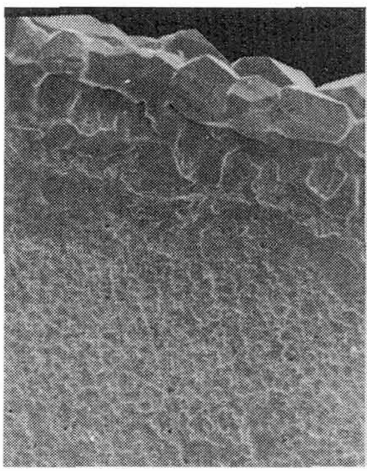

$\longmapsto-100 \mu \mathrm{m}$

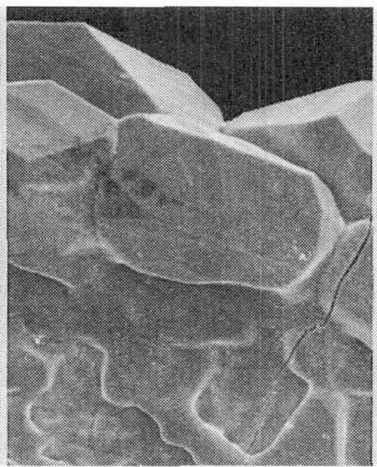

$\longmapsto 10 \mu \mathrm{m}$

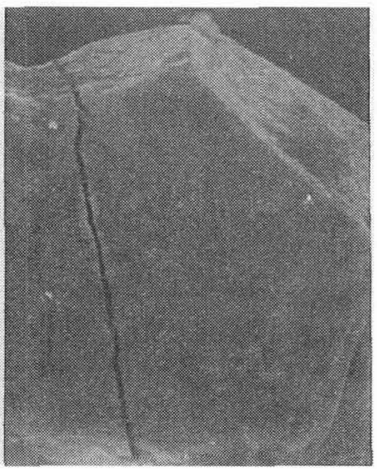

$\longmapsto 10 \mu \mathrm{m}$

Figure 9: $\mathrm{SiC}$ layer grown at substrate edge $\left(1200^{\circ} \mathrm{C}, 5.18 \times 10^{-3} \%\right.$ precursor, $\mathrm{H}_{2}$ flow $\left.1000 \mathrm{ml} / \mathrm{min}\right)$ 


\subsubsection{Crystalline SiC deposits}

Under specifically selected conditions $\left(1300^{\circ} \mathrm{C}, 5.18 \times 10^{-3} \%\right.$ precursor, gas flow rate $\left.1000 \mathrm{ml} / \mathrm{min}\right)$ and especially at higher deposition temperatures, faceted crystals are observed within the large monolithic areas (Figure 10). The crystal facets are mainly triangular; in some cases fiber-like crystals were observed. Most of these crystals have the same orientation within one monolithic area. This indicates that these large areas are actually monocrystalline. However they were so thin that no X-ray diffraction patterns of the coating could be obtained; thicker specimens showed the $\beta-S i C$ pattern.

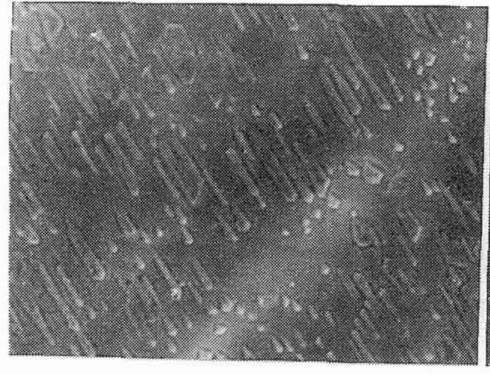

$\longmapsto 10 \mu \mathrm{m}$

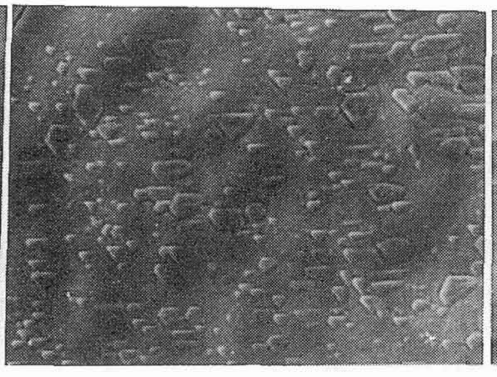

$\longmapsto 10 \mu \mathrm{m}$

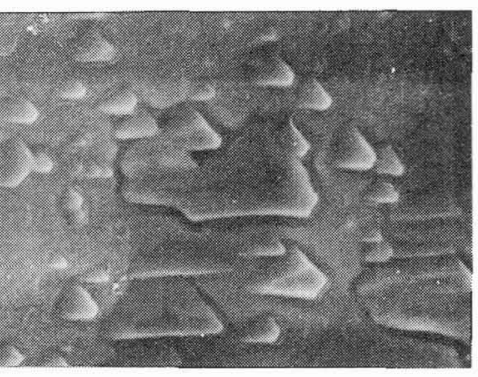

$\longmapsto 1 \mu \mathrm{m}$

Figure 10: Crystalline area within monolithic layers $\left(1300^{\circ} \mathrm{C}, 5.18 \times 10^{-3} \%\right.$ precursor, $\mathrm{H}_{2}$ flow $\left.1000 \mathrm{ml} / \mathrm{min}\right)$

\subsection{Comparison with MTS and TMS}

MTS is a well-known precursor for $\mathrm{SiC}$ coatings in the CVD process because of its 1:1 molar ratio of silicon to carbon. However the etching on Si substrate was observed due to the formation of C-containing radicals $[19,28,29]$. By using 1.2-dimethyldisilane as precursor to deposit SiC coatings, there exists no etching problem, and meanwhile the same molar ratio of silicon to carbon is maintained, which keeps the advantages as MTS has.

The TMS (tetramethylsilane) was used as precursor because it supplies Si and $\mathrm{C}$ from individual molecules free from chlorine. Polycrystalline $\beta$-SiC coatings could be grown by LPCVD process of TMS. The morphology strongly depends on the process parameter [25]. A low pressure seems to be essential for the coatings deposition, while SiC coatings can be obtained by 1.2-dimethyldisilane under atmospheric pressure. As a new raw material, 1.2-dimethydisilane has shown advantages in SiC coatings preparation, and further research is significant.

\section{CONCLUSIONS}

$\beta-S i C$ coatings can be deposited easily on inductively heated WC-Co substrates at temperatures between $1000-1400^{\circ} \mathrm{C}$ by the thermal decomposition of 1,2-dimethyldisilane under normal pressure in hydrogen atmosphere. It was demonstrated that this silicon compound is an advanced precursor for the $\beta$-SiC coatings.

The reaction temperatures influenced the $\mathrm{SiC}$ growth rate as well as the microstructure of the coating. The $\mathrm{SiC}$ growth rates were found to peak sharply at $1100^{\circ} \mathrm{C}$, decreasing rapidly above that temperature. Different reaction mechanisms occurred in the two temperature zones. Below $1100^{\circ} \mathrm{C}$ fine grained, unfacetted, cauliflower-like coatings were obtained. Above $1200^{\circ} \mathrm{C}$ faceted and monolithically crystallized coatings were formed. The morphology differences are also associated with the coating growth rates.

The precursor concentrations in the reaction gas should be relatively low in order to obtain homogeneous coatings characterized by good crystallinity as well as to avoid "smoking", i.e. nucleation in the gas phase. 


\section{ACKNOWLEDGMENT}

We acknowledge financial support by the Austrian Science Foundation. Thanks also go to Dr. B.Kieffer and Dr. J.Oakes (Teledyne Advanced Materials, Huntsville, Alabama, USA) for providing the hard metal substrates free-of-charge.

\section{REFERENCES}

[1] Sumakeris J.J., Rowland L.B., Kern R.S., Tanaka S. and Davis R.F., Thin Solid Films, 225 (1993) 219

[2] Larris G.L. and Wang C.Y-W. (Eds), Amorphous and Crystalline Silicon Carbide, Springer Proc. Phys., 34 (1989)

[3] Ramann M.M., Wang C.Y-W and Larris G.L. (Eds), Amorphous and Crystalline Silicon Carbide II, Springer Proc. Phys., 43 (1989)

[4] Fuma H., Miura A., Tadano H., Sugiyama S. and Takigawa M., Jpn. J. Appl. Phys., 27 (1989) 2143

[5] Sugii T., Yamazaki T. and Ito T., IEEE Trans. Electron. Devices, 37 (1990) 2331

[6] Jiang X. and Klages C.P., Diamond Relat. Mater., 2 (1993) 1112

[7] Kong H.S., Glass J.T. and Davis R.F., Appl. Phys. Lett., 49 (1986) 1074

[8] Nishino S., Ishida H. and Saraie J., Electrochem. Soc., Extended Abstract, 89(2) (1989) 691

[9] Golecki I., Reidinger F. and Marti J., Appl. Phys. Lett., 60 (1992) 1703

[10] Fuyuki T., Makayama M., Yoshinobu T., Shiomi H. and Tatsunami H., J. Cryst. Growth, 95 (1989) 461

[11] Veheskel J., Agram S. and Dariel M.S., Proc. 5th Isr. Mater. Eng. Conf. 1991, 135

[12] Choi J., Kim D.R. and Jeun S., J. Eur. Ceram. Soc., 9 (1992) 357

[13] Schmidbauer H. and Hager R., Z. Naturforsch., 43b (1988) 571

[14] Minato K. and Fukuda K., J. Nucl. Mater., 149 (1987) 233

[15] Tsui P. and Spear K.E., Mat. Sci. Res., 17 (1984) 371

[16] So M.G. and Chun J.S., J. vax Sci. Technol., 6 (1988) 5

[17] Krautwasser P., Begun G.M. and Angelini P., J. Am. Ceram. Soc., 66(6) (1983) 424

[18] Loumagne F., Langlais F. and Naslain R., Proceedings of the Ninth European Conference on Chemical Vapour Deposition, 527, Tampere, Finland, 22-27 Aug. 1993, Edited by Tapio Mäntylä

[19] Chien C.Chiu, Desu B., and Ching Yi Tsai, J. Mater. Res., 8(10) (1993) 2616

[20] Besmann T.M., Sheldon B.W., Moss III T.S. and Kaster M.D., J. Am. Ceram. Soc., 75(10) (1992) 2899

[21] Schlichting J., Pow. Metall. Inter., 12(3) (1980) 141

[22] Besmann T.M. and Johson M.L., Proceedings of Inter. Symp. on Ceram. Mat. and compound for Engine, 443, Las Vegas, NV 1988, Edited by V.J.Tennery, Am. Ceram. Soc., Westerville, OH. 1989

[23] Fischman G. S. and Petuskey W T., J. Am. Ceram. Soc., 68(4) (1985) 185

[24] Kingon A.I., Lutz L.J., Liaw P. and Davis R.F., J. Am. Ceram. Soc., 66 (8) (1983) 558

[25] Henry F., Marti P., Casaux Y., Combescure C., Figueras A., Madigou V., Rodriguez-Clemente R., Mazel A., Sevely J. and Armas B., Proceedings of the Ninth European Conference on Chemical Vapour Deposition, 329, Tampere, Finland, 22-27 Aug. 1993, Edited by Tapio Mäntylä

[26] Chehouani H., Benet S., Armas B., Combescure C., Figueras A. and Garelik S., Proceedings of the Ninth European Conference on Chemical Vapour Deposition, 131, Tampere, Finland, 22-27 Aug. 1993, Edited by Tapio Mäntylä

[27] Hengge E., Zechmann A., Hofer F., Pölt P., Lux B., Danzinger M. and Haubner R., Adv. Mater., 6 (7/8) (1994) 584

[28] Ikoma K., Yamanaka M., Yamaguchi H. and Schichi Y., J. Electrochem. Soc., 138 (1991), 3028

[29] Weber M.E. and Armentrout P.B., J. Physis. Chem., 93 (1989),1596 